(C2019, Elsevier. Licensed under the Creative Commons Attribution-NonCommercialNoDerivatives 4.0 International http://creativecommons.org/about/downloads

cc) 


\title{
Geography, Economic Structures and Institutions: A Synthesis*
}

\author{
Collin Constantine ${ }^{\dagger}$ Tarron Khemraj ${ }^{\ddagger}$
}

\begin{abstract}
This paper develops a conceptual framework and presents three case studies that show how differences in economic structures are the fundamental cause of differences in economic development. This insight is derived from a synthesis of competing hypotheses. A given economic structure gives rise to a particular distribution of income - an important source of de facto political power. The mechanics of economic change or persistence are in turn determined by the intensity of competition between de facto and de jure political powers and the resolution to this contestation. We use historical evidence to show that geography played a pivotal role in shaping economic structures and demonstrate that geography is still important in explaining the Guyana-Barbados divergence. In the case of Mauritius, it was the good fortune of sugar rents that gave rise to a distributional bargain and institutions of production (industrial policies) that led to the Mauritian miracle.
\end{abstract}

Keywords: geography, economic structures, institutions, inequality, growth JEL Classification: O13, O14, O15, O43, P48

*We are grateful to James Galbraith, Erik Reinert, Andy Sumner, participants at the 20th Anniversary Conference of the Association for Heterodox Economics and two anonymous referees for useful comments.

${ }^{\dagger}$ Collin Constantine is a PhD student at Kingston University, London. Department of Economics; Penrhyn Road, Kingston Upon Thames, Surrey KT1 2EE, UK. Email:k1543752@kingston.ac.uk.

$\ddagger$ Tarron Khemraj is Professor of Economics and International Studies at the New College of Florida, 5800 Bay Shore Road Sarasota, FL 34243. Email:tkhemraj@ncf.edu. 


\section{Introduction}

How rich countries got rich and why poor countries stay poor gets to the heart of concerns regarding economic change and persistent under-development. There is no shortage of theories that seek to explain comparative economic development. In this paper, we zoom in on three basic narratives - geography, institutions and economic structures. By geography we mean those natural factors (climate, temperature, soil fertility) that affect economic outcomes (Sachs 2001; Khemraj 2015) and institutions refer to the humanly devised constraints that structure political, economic, and social interaction (North 1991). We define economic structures as the aggregate representation of a country's technological capabilities (Constantine 2017b). This can be measured by summary indices such as economic complexity of a country's export basket (Hidalgo et al. 2009). Thus, there are low, mid and high-technology economic structures. This article synthesizes these useful insights into a coherent framework that in our view can better explain how rich countries got rich, why poor countries stay poor and the mechanics of emerging economies.

The goal of this synthesis is to build on the insights of various traditions in economic development to advance a new narrative for the political economy of development. It goes as follows. Economic change or persistence is the outcome of distributional conflict. The haves - those with economic assets and power ${ }^{1}$ - have vested interests in the status quothe present economic structure and its corresponding distribution of resources. The have nots contest this allocation and the structural origins of their dispossession - the economic structure and politco-institutional forms. Inclusive economic change - economic growth with lower inequality - is the outcome of an elite bargain that has two pillars: 1. An agenda for economic transformation towards a more complex and technology-intensive economic structure and 2. The reduction of distributional tensions in time $t$. Imagine the latter as a minimal welfare state - some short-term capital-labour compromise and the former as a long-term compromise that propagate Kuznets dynamics - changing income distribution as a consequence of structural changes.

A production structure - we use this interchangeably with economic structure - based on a wide mix of complex products has a wider range of occupational choices, flatter hierarchy of occupational structure, wider diffusion of skills and knowledge, and deepening class

\footnotetext{
${ }^{1}$ In our set up, there are de jure (e.g. political institutions) and de facto (e.g. economic resources) sources of power. Power is thus defined as the de jure or de facto ability to direct or influence the behaviour of others or the course of events.
} 
consciousness, thus producing lower income inequality. Further, as structuralists have long argued, complex economic structures at the macro level or high-technology commodities at the micro level are growth enhancing; if only because they have higher income elasticity of demand in export markets, are more conducive for technical change and support higher wages and profits. These insights reveal the following. First, production structures jointly determine economic growth and income distribution. Second, economic change or persistence is determined by how social contestation change or reinforce the economic structure respectively. Our synthesis shows that historically, geography determined the technological content of economic structures (economic growth) and by extension, the distribution of income and its corresponding intensity of distributional conflict.

Through the use of case studies - Guyana, Barbados and Mauritius - and using a comparative historical analysis methodology that is substantivist in nature, we show that institutions of production - industrial policies - as opposed to simply institutions of exchangeprotection of private property - engender growth enhancing structural transformation. The Mauritian miracle best demonstrates this, and the Guyana and Barbados cases highlight the relevance of geography in shaping economic structures and income distribution. Specifically, Barbados' natural endowment of beaches led to tourism services and a superior growth process as compared to Guyana, which is still dependent on low-technology commodities like sugar and gold. Tourism services have a high luxury content with higher income elasticity of demand in export markets. However, Barbados, like Mauritius in more recent years, has developed an offshore financial centre since the 1970s that produces an extractive growth process - economic growth with increasing inequality. The distributional implications of financial services are rising top incomes (Kaplan and Rauh 2010) - this has been the Mauritian story since the mid 2000s - a striking contrast to its miracle years (1970s to mid 2000s) of falling top incomes and industrialization.

The case studies reveal that top incomes in the respective countries have deep colonial origins and the inclusive Mauritian miracle is the outcome of an elite bargain, largely facilitated by the good fortune of sugar rents. In contrast, high income inequality still plagues Barbados and Guyana since their economic elites have been mostly unchallenged. Consequently, top income earners use their de facto power to influence economic policy that entrenches their income position. We argue that this is a fundamental explanation for why both Barbados and Guyana still rely on a production structure of low-technology content.

Our new narrative and case studies reveal distributional contestation and production 
structure as deep determinants of relative development, as compared to the new institutional economics tradition that emphasizes distribution and political institutions. Our analytical framework and case studies demonstrate that the choice and performance of political and economic institutions depend on which interest group wins the distributional conflict and the technology-intensity of the economic structure. Though the traditions of geography, economic structures and institutions are competing hypotheses, they share sufficiently common features to provide a synthesis. Our starting point is economic structure as the basis of economic growth. In pre-modern times, geography was the sole determinant of production possibilities - economic structure. Further, economic institutions form the incentive system to reinforce or change the production structure and as the case studies show, institutions of production rather than of exchange promote growth enhancing structural transformation.

The remainder of the paper is organized as follows. Section 2 provides a brief overview of the three fundamental causes of relative development and section 3 presents our theoretical framework. Section 4 outlines the case studies and section 5 concludes.

\section{Three Fundamental Causes}

In this section, we sketch the three basic hypotheses of comparative economic development.

\subsection{Geography}

Machiavelli (1531) is among the earlier proponents of the geography hypothesis and in recent times a substantial empirical literature has emerged. In its simplest form, Sachs (2001) documents a positive relationship between climate and temperature on the one hand and economic development on the other. More complex variants highlight the disease environment (Sachs and Malaney 2002), natural resource endowments (Sachs and Warner 2001), transport conditions (Rappaport and Sachs 2003) and type of agriculture (Khemraj 2015). Given these competing mechanisms, the debate centers on the causal channels. Sachs and his co-authors contend that the central mechanisms are through geography's impact on agricultural productivity and the disease environment. Warm climates are prone to tropical diseases and extremes of heavy rainfall or drought, which adversely affect health conditions and agricultural growth respectively. Khemraj argues that polder agriculture incurs high drainage and irrigation costs, which lead to wage suppression and extractive growth. 


\section{$2.2 \quad$ Institutions}

Acemoglu et al. (2003) claim that geography, in particular its disease channel, has an indirect effect on economic development through institutions. They argue that malaria and yellow fever were decisive factors in determining European settlement in newly colonized areas. Naturally, European settlement was limited in areas with high mortality rates and the converse was true. In the latter case, Europeans were more likely to establish protection for private property and some degree of adult suffrage, both of which encourage social and economic development. The new consensus is that economic institutions are the fundamental cause of long run growth, that is, the protection of private property (Acemoglu et al. 2005). Since this is dependent on the political rules and system - political institutions are deep determinants of economic performance (North 1990).

\subsection{Economic Structures}

Structuralists argue that non-settlement colonies are relatively poor because of their lowtechnology exports (e.g. sugar) that produce declining terms of trade (Singer 1950), low wages and weak inter-sectoral linkages (Prebisch 1950). The earlier proponents of this tradition date back to Botero's Greatnesse of Cities (Reinert 2016), which explained why cities were the repositories of wealth - they had extensive divisions of labour, technical change and high value added as a ratio to imported raw materials. Thirlwall (1979) presents a theoretical model that demonstrates how a country's rate of economic growth is determined by the growth of foreign demand and the ratio of income elasticities of demand for exports and imports. Countries with more limited production technologies have higher elasticities of demand for imports. This thesis of balance of payment constrained growth-growth constrained by low-technology economic structures - has been verified by numerous empirical studies. See Bertola et al. (2002) for focus on LAC, McCombie (1997) for UK, USA and Japan, and Hussain (1999) for African and East Asian countries. 


\section{A Synthesis}

\subsection{Economic Structure}

Historically, geography was the early determinant of what and how goods were produced (see Diamond 1999: chap. 2, 5). Land-locked countries had qualitatively different production possibilities as compared to islands or geographies with easier access to coast lines. In the West Indies, climate and soil fertility were crucial in forming their sugar economies, while natural gifts like gold and silver laid the foundation for mining economies in Spanish America (Engerman et al. 2002). But with modern technologies, the geographical origins of production possibilities (what and how) become less important. Still, the historical value of geography and its demise present a crucial insight - that the what and how are central to the process of economic change. Our geographical synthesis is simply to present a framework that is consistent with historical time and implies the following.

$$
\text { geography } \Longrightarrow \text { economic structure } \text {. }_{\text {. }}
$$

\subsection{Economic Performance \& Distribution}

Why do economic structures matter for growth? First, higher value added economic activities are produced in imperfectly competitive markets that keep wages and profits elevated for longer periods. This sustains aggregate demand and internal growth. Second, Dasgupta and Stiglitz (1980) explain that imperfectly competitive market structures are more conducive for innovation and technical progress - this is recently supported by Andreoni (2014). Third, Constantine (2017b) notes that production structures based on increasing returns economic activities are more likely to fertilize the seeds of democratic transition and consolidation; and following Aghion et al. (2008), democratic property rights are crucial for the diffusion of technology. Fourth, economic activities with increasing returns enjoy higher income elasticity of demand in export markets and this make them ideal growth propellers for highly open economies (Thirlwall 1979). Fifth, Constantine (2017b) notes that job ladders are longer for technology-intensive economic activities and serve as an important mechanism for upward labour mobility, which improves the distribution of income. Sixth, Constantine (2016b) and (Hartmann 2014: 60-61) contend that a country's economic structure is an important determinant of the allocation of human capital between entrepreneurship and rent seeking 
(broadly defined); and therefore, indirectly affects the growth process through the labour market. It follows that technology-intensive production structures are growth enhancing because they stimulate demand for wealth creating activities like entrepreneurship.

Economic structures in period $t$ not only determine the size of the pie, but also the distribution of income in $t+1$.

$$
\text { economic structure } \left._{t} \Longrightarrow \begin{array}{c}
\text { economic performance }_{t} \\
\text { income distribution } \\
t+1
\end{array}\right\}
$$

A production structure based on a wide mix of complex products is more likely to have a wide range of occupational choices, relatively flat hierarchy of occupational structure, wide diffusion of skills and knowledge and deepening class consciousness (unionization) (Hartmann 2014: 70). It follows that relatively complex economies have structural limits to the growth in top incomes, high wage shares and a strong middle class-less inequality. This is where supply and demand intersects our framework. High-technology production structures engender relatively high wage shares and robust demand-led growth. See Hartmann et al. (2017), Hartmann et al. (2016), Constantine (2017a), Galbraith and Berner (2001) and Conceicao and Galbraith (2002) for empirical support. Hartman and his co-authors find that production structure as proxied by the Economic Complexity Index (ECI) is inversely related to the Gini for over 150 countries between 1963-2008. They also calculated a Product Gini Index (PGI) - a weighted average of the Gini coefficients of the countries that export a product. Products like cocoa beans, flour and animal hair are consistent with Gini coefficients that exceed 0.5, while textile machinery and paper machine parts produce much lower Gini coefficients. Other approaches include the University of Texas Inequality Project, which uses industrial statistics to produce inequality measures like the Theil Index.

\subsection{Power \& Institutions}

The distribution of income is a fundamental determinant of de facto political power - that power not allocated by formal political institutions like a constitution or government agency. When income inequality is extremely high, say 19th Century Europe or present day US and Europe - the rich have disproportional influence on formal political institutions (Piketty 2014; Stiglitz 2013) and (Engerman et al. 2002: 72-73). 
$\left.\left.\begin{array}{l}\text { income distribution }_{t} \\ \text { political institutions }_{t}\end{array}\right\} \Longrightarrow \begin{array}{r}\text { de facto political power } \\ \text { de jure political power }\end{array}\right\}$

De jure political power is derived from political institutions, say a constitution that outlines the powers of a President or the principle of separation of powers. But we have just noted how de facto political power is leveraged to influence formal political institutionslike a wealth-based requirement for voting. We argue that there is a complex interaction between de facto and de jure political powers and the strength of this interaction depends on the extent of income inequality. When extreme inequalities of income are present, de jure political power is hijacked by the de facto influence of the rich. Conversely, when the growth in top incomes is constrained, there is meaningful separation between de facto and de jure political powers.

We illustrate below how de facto power influences future political institutions. Elites infinitely prefer to exercise control and influence over time and one way of committing current and future politicians is by legislating elite-friendly laws. This is effective in developed countries where institutions are enforced but in the case of developing countries, enforcement is the exception rather than the rule. Public and academic interest in reducing corruption demonstrate the problem of enforcing certain legislations in these countries. In cases where political institutions are inadequately enforced, elites find other means of influencing current and future policy. One effective way is to protect the basis of their economic position - the present economic structure. It follows that elites influence de jure political power to enforce economic institutions that reinforce the economic structure. This is shown below.

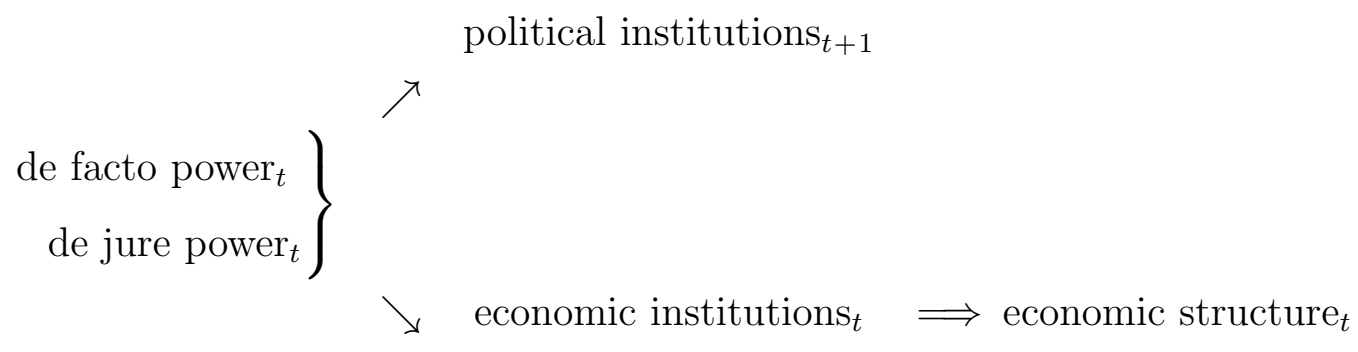

The strategy of promoting structural rigidity is the same as advancing elite-friendly legislation - both are slow changing and consequently, serve as effective methods of exercising power and influence over time. One noteworthy example is Latin America's economic elites 
prevention of land reform (Engerman et al. 2002: 64).

It is important to draw the distinction between institutions of production -industrial polices: tariffs, subsidies, cheap credit and institutions of exchange-property rights and the rule of law. Reinert (2007) argues that institutions of production promote growth enhancing structural change, while institutions of exchange engender structural and institutional inertia. Reinert explains that property rights may enhance growth by exploiting existing opportunities or creating new opportunities for trade within an existing production structure.

Pulling all the pieces together leads to the following schematic of our framework, where the dotted lines illustrate the various competing hypotheses (Figure 1). Economic structure and income distribution are our two state variables ${ }^{2}$, knowledge of these in time $t$ is sufficient to determine all other variables in the system. A country's economic structure in time $t$ determines its current economic performance and income distribution in $t+1$. Historically, geography played a central role in the formation of economic structures, this is less so today but not unimportant. Income distribution in time $t$ determines the complex relationship between de facto and de jure political powers and influences the evolution of political institutions over time and the type of economic institutions enforced. These in turn determine the economic structure - either structural change or persistence.

The fundamental source of persistence is the economic structure and it has two dimensions. First, it is slow changing and second, it generates an income distribution and corresponding distribution of de facto power that influences current de jure political power to maintain the economic structure in time $t$. Notwithstanding the tendency towards persistence, our model emphasizes the potential for change. Shocks to de facto political powersay, through warfare, revolutions or epidemics that significantly alter the distribution of income - can lead to fundamental changes in both political and economic institutions and consequently, the economic structure. Alternatively, shocks to the economic structure, say through technological innovations or donor policy intervention, alter the growth calculus, the distribution of income and the evolution of the system.

How does our framework relate to the model presented by Acemoglu et al. (2005). Both frameworks agree that the distribution of resources and its evolution are central determinants of economic persistence and change. However, unlike our model, these scholars posit that political institutions are the second state variable. We place less emphasis on political insti-

\footnotetext{
${ }^{2}$ A state variable is one of the set of variables that describe the behavior of a dynamical system, particularly its future behavior in the absence of shocks to the system.
} 
Figure 1: A Synthesis

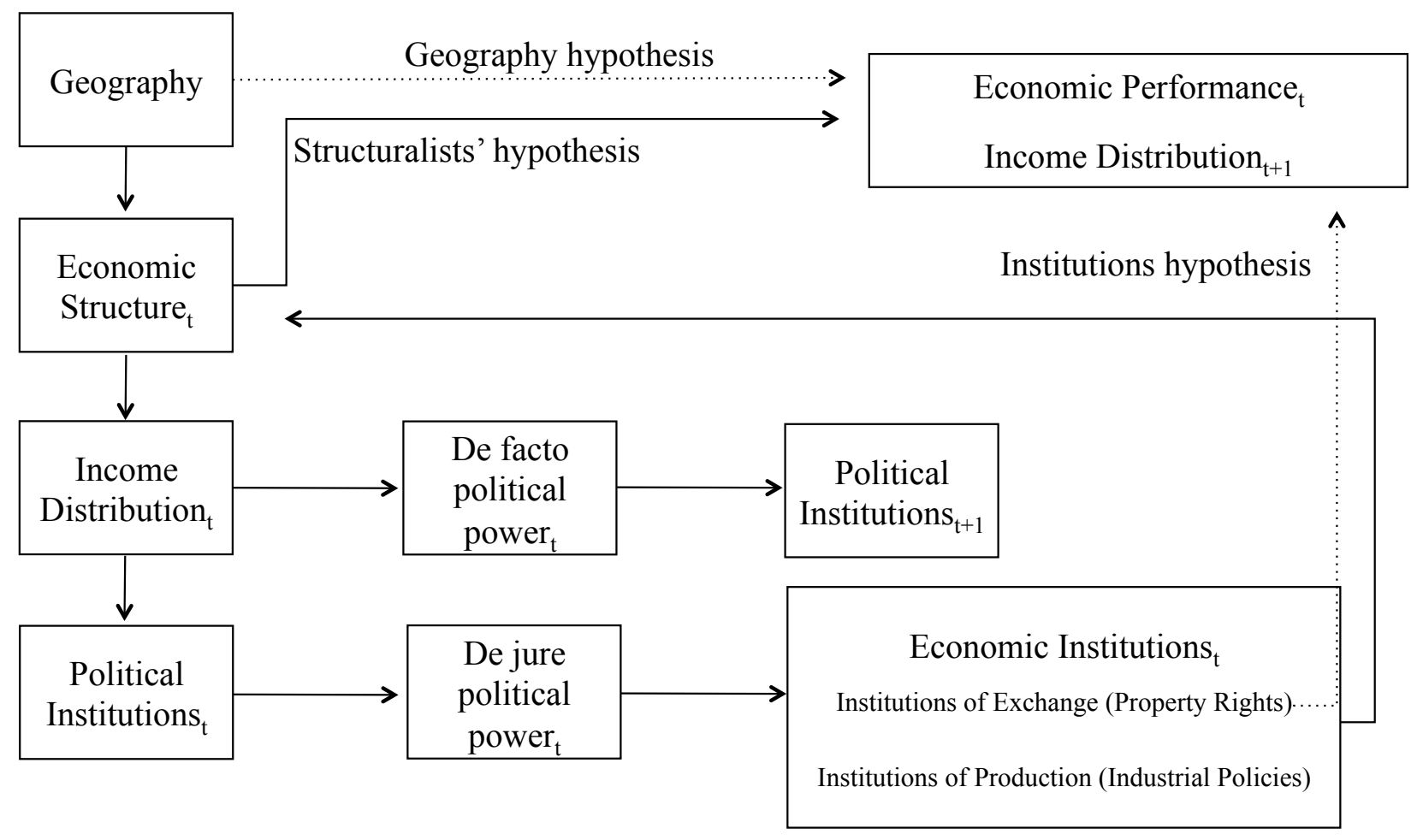

tutions and their de jure power because their effectiveness largely depend on the distribution of income and the corresponding distribution of de facto power. Moreover, our framework demonstrates that the distribution of resources is not independent of an economy's production structure. Thus, our framework recommends industrial polices rather than institutional reforms (institutions of exchange) as a means to economic change.

\section{Case Studies}

In the case studies that follow, we do not provide a detailed account of the political and economic history of the respective countries. Rather, by way of analytical narratives we illustrate the workings of our model.

\subsection{Guyana}

Guyana, like many of its sister colonies in the Caribbean, was used primarily for sugar cultivation. Its immediate hinterland made inland farming too expensive and its distance from 
the coast made transport and trade prohibitive (Taeuber 1952; Khemraj 2015). Khemraj notes that the Dutch colonizers opted for the coastland for settlement and agriculture after originally settling in the riverine hinterland. But the coastland is below sea level and thus, prone to flooding, which made agriculture a costly economic activity (Williams 1945). Sustained profits required wage suppression, high sugar prices and political lobbying by the planter class for preferential prices (Adamson 1972: 33). It follows that geography played a central role in determining the location of settlement and costs of production. Moreover, soil fertility placed a premium on agricultural produce - sugar - a low-technology commodity with diminishing returns.

We have demonstrated how low-technology commodities like sugar, produce high inequality and when this is paired with political inequality (slavery) - Guyana becomes an oligarchic society. Therefore, to understand the dynamics of change or lack thereof in the Guyana case, its low-technology economic structure and high income inequality must be central to the analysis. These are the two state variables in our framework.

The abolition of slavery in 1834 gave way to the village movement (Rodney 1981) - the acquisition of land by ex-slaves for purposes of housing and non-sugar farming (Josiah 1997). This was facilitated by high saving propensities and Bourne (1975) estimates these to be between 0.21-0.41 based on annual wages and land outlays. It is important to emphasize here that the village movement and its consequent development of an independent peasantry were the outcome of Guyana's land size (geography) relative to its labour supply (Farley 1964). It follows that geography played a key role in enhancing the bargaining power of ex-slaves vis-a-vis the planter class - (Rodney 1981: 648) notes that they bargained for higher wages and better working conditions. This is a clash of interests that threatens the distribution of political and economic power and the economic viability of high-cost sugar cultivation.

This formidable threat led to a new economic institution - indentureship - that sought to do two things: 1. Reduce the labour cost of sugar production and by extension, reinforce the production structure and 2. Reduce aggregate wage share and therefore, maintain high income inequality. But indentureship does not address the geographical origins of the emerging independent peasantry. This led to another key economic institution-land policy (Farley 1954), which prevented ex-slaves from acquiring more lands. Moreover, Bourne (1975) explains that prohibitive taxes were imposed on the commodities consumed by exslaves and Danns (1997) contends that they were deliberately denied access to credit. These economic policies were the sources of persistent inequality and limited structural change - the 
land policy prevented the growth of non-sugar economic activities. This historical account demonstrates our equilibrium of political power, institutions and economic structure.

The policy of indentureship led to the immigration of Chinese, Indians and Portuguese and Guyana's ethnic cleavages or distrust served as the basis of political mobilizationeven today. It follows that distributional conflict assumes a multi-ethnic dimension and complicates the evolution of political institutions and the dynamics of structural change and persistence. For example: growth-enhancing structural change produces winners and losers and the ethnic distribution of the payoff structure is central in determining whether or not (or how) structural change is promoted. In terms of the how-structural change in the direction of inequality-promoting economic activities serve existing interests and we call this primitive diversification. With the inflow of indentured labourers, colonial administrators encouraged Portuguese to undertake non-tradable economic activities like commerce and retail trading (Moore 1975). These non-tradables increased income inequality and elevated the economic status of the Portuguese and over time even rivaled the plantocracy (Wager 1975).

Constantine (2017c) presents new evidence to show that the richest 10 percent in Guyana owns 41 percent of household income as of 2013, the same level of income concentration in 1960. Further, he posits that this elite group has its colonial origins in the rise of the Portuguese. Why is this consequential to economic change? At the most basic level, economic elites seek to protect the economic basis of their top incomes or only advocate for primitive diversification. Here lies an important source of Guyana's failure to ignite the process of growth-enhancing structural transformation. Chandisingh (1983), Thomas (1988) and Ishmael (1993) argue that the de facto power of elites were largely unchallenged under both dictatorship and democracy in Guyana. For this reason, only primitive diversification took place under both political systems. In present day Guyana, economic elites are not exclusively of Portuguese origin, they are now a complex web that includes both Afroand Indo-Guyanese but this hardly alters the story - these economic elites have entrenched interests in promoting only primitive diversification.

The evolution of Guyana's productive base has been along the periphery of the global production matrix. It has moved away from mono-crop sugar production to non-tradable economic services and to a tradable basket of primarily rice, sugar, bauxite, gold, diamonds and non-traditional agriculture. Like sugar in its colonial history, bauxite served as the principal export in the 70s and gold now plays a similar role. Given this primitive diversification, it is no surprise that Constantine (2017c) finds little evidence of a Kuznets wave as it relates 
to top incomes in Guyana.

Recently, Guyana has discovered oil and invited Exxon Mobil to undertake further exploration and production. Like other low-technology commodities, oil is located on the periphery of the global production matrix but has the potential to transform the economy. However, initial conditions of high income inequality does not augur well for an oil boom; the latter is likely to exacerbate distributional tensions. Guyana's own history also suggests that the oil economy is likely to do more harm than good. As noted earlier, sugar, bauxite and gold were at different times dominant exports and presented similar possibilities as does the oil economy. But as in the present day, initial conditions under colonialism were aligned in the interest of special groups that ensured that the growth process was extractive and economic diversification was primitive.

Inevitably, we have omitted numerous details about the history of Guyana, in particular, its well-known ethnic preferences and voting pattern (Khemraj 2016). This is less important for the purpose of illustrating the workings of our model. Guyana's ethnic conflict divides the working class and exacerbates the distributional conflict, which only reinforces one of our state variable - inequality - as a law of motion that explains Guyana's economic and political development. When this law of motion is juxtaposed with a low-technology productive structure, Guyana's persistent under-development or lack of growth enhancing and inclusive structural change become a stable equilibrium outcome. Fundamentally, its erratic growth and highly unequal distributional outcomes are determined by the low-technology content of its productive base.

\subsection{Barbados}

The colonial economic structure of Barbados - mono-crop sugar production - is not appreciably different from colonial Guyana. Yet, a substantial divergence between these countries is observed (DaCosta 2007; Grenade and Lewis-Bynoe 2011). The Guyana case allows us to demonstrate the dynamic equilibrium of under-development with the use of our framework, while the Barbados case is well positioned to illustrate the workings of relative development. Unlike Guyana, Barbados has a unique geographical endowment. It was well suited for permanent residency and developed a relatively large white settlement (Beckles 2007: 53) and (Dawson 2011: 136). Even in present day, Barbados is widely known for its luxury tourism - a key earner of foreign exchange and means of employment. 
A short digression on European settlement and the development of "inclusive" institutions is useful here. While Barbados had a relatively large European settlement, the historical evidence shows that Barbados had an extractive governance framework; contrary to the prediction of New Institutional Economics. Barbados was the only Caribbean island to not abolish its system of elite representation in favour of Crown Rule (DaCosta 2007). Nicholls (1969) argues that Barbados was the same as it had been three hundred years earlier; instead of slaves and planters, it was made up of planters and a free but landless population. It follows that Barbados' relative development cannot be explained by "inclusive" institutions through the settlement of Europeans - the causal explanation must lie elsewhere. Finally, the legacy of extractive institutions plagues modern Barbados. One example is its Defamation Actoriginally conceived in colonial Barbados to silence dissenters - which presently engenders a norm of self-censorship (Tennyson and Barrow-Giles 2008) and threatens potential corporate whistleblowers (Alleyne et al. 2017). Collectively, these lead to what Tennyson and BarrowGiles (2008) call a culture of fear.

Dunn (1969) notes that the great majority of landholders were small farmers in colonial Barbados and DaCosta (2007) attributes this to the small size of the island, which led to high land prices and modest landholdings. Dunn estimates that 71 percent of landholders were small planters - landholders with fewer than twenty slaves in 1679. Also, Barbados' small land size facilitated intense sugar cultivation of the entire island (Beckles 2007). Furthermore, Cumper (1962) notes that the oligarchic ownership of arable land remained until the 1950s. Downes (1987) provides evidence to show that in 1970 the top 10 percent of landowners owned 77 percent of the land in Barbados. This historical account and recent evidence (Constantine 2017a) firmly establish Barbados as an island with high income concentration.

A critical juncture of the divergence between Guyana and Barbados is the immediate post-emancipation period. While Guyana experienced rising labour cost (Bulmer-Thomas 2012: 74) and growth in the de facto power of ex-slaves, Barbados maintained its plantation system and increased output immediately after abolition (Bulmer-Thomas 2012: 60). Unlike Guyana, the land to labour supply ratio is small and this kept ex-slaves in a constant state of tenantry. In other words, after abolition, ex-slaves continued to work for the plantation enterprise (Barrow 1983) and this kept wages low and profits and output high as compared to Guyana. This demonstrates one mechanism of how the geographical differences between Guyana and Barbados were historically consequential.

Economic inequality and the geographical endowment that valorize luxury tourism en- 
gender a significant change in the production structure of the Barbados economy. Here lies the fundamental source of the Barbados-Guyana divergence. Why does luxury tourism produce more stable growth than low-technology commodities? First, it has a higher income elasticity of demand in world markets (Onafowora and Owoye 2012) and this ties Barbados' growth cycle to those in developed countries. Second, the full exploitation of luxury tourism leads to institutional spillovers that are growth intensive. Constantine (2016a) explains that luxury commodities have certain institutional requirements that are similar in nature to the institutions required to fully exploit technology-intensive economic activities. In the case of beach tourism - the Barbados case - institutional and organizational inputs range from low crime to adequate public services. In the absence of these, travel advisories from foreign governments are likely to encourage tourists to stay away. In short, the institutional inputs for luxury tourism create an attractive business climate.

Did the shift to luxury tourism promote primitive diversification or inclusive structural change? To provide an answer, we need to understand the shift to tourism ${ }^{3}$ services as a change to a wider range of services, including financial services (Premdas 2013; Barrow 1983). Both tourism services and the FIRE ${ }^{4}$ economy were developed around the 1970s (Bulmer-Thomas 2012: 617). While the FIRE economy and luxury tourism generated better economic performance relative to Guyana, they also engendered an extractive growth process in Barbados. See Premdas (2013) and Barrow (1983) for a discussion on how the old commercial elites transformed themselves into conglomerates that dominate the distributive trade and the FIRE economy. Like the sugar economy in colonial Barbados, the FIRE economy serves as the economic foundation of the oligarchy.

Consistent with our framework, we have demonstrated how Barbados' geographical endowments shape its economic structure and consequently its growth mechanics and income distribution. Further, we have illustrated the structural origins of Barbados' "inclusive" institutions. But when we take a closer look beyond the hidden abode of production and repeal the veil of "inclusive" institutions, we observe a deeply extractive growth process. While de jure political power is in the hands of the voting masses, de facto political power is concentrated in a group with close ties to Barbados' colonial legacy (Barrow 1983).

The Guyana-Barbados comparison demonstrates the salience of geography in forming

\footnotetext{
${ }^{3}$ Barbados had experienced a short stint of manufacturing but its government industrial plan of 1978-1982 noted that the smallness of the island is a natural constraint, see Potter (1981) for details.

${ }^{4}$ FIRE economy refers to Finance, Insurance and Real Estate.
} 
production possibilities - low-technology and high-luxury economic activities in Guyana and Barbados, respectively. Notwithstanding this qualitative difference in economic structures, their colonial history established the foundation of extreme economic and political inequality that affect the evolution of political and economic institutions today. Initial conditions of high economic inequality firmly establish de facto political power in the hands of a select group, usually with close colonial ties. It is this economic group that guides economic transformation in the direction that fortifies their income position. However, this outcome is not inevitable, but only the consequence of unchallenged vested interests. It is unlikely that vested interests will facilitate an inclusive economic transformation but there is no guarantee that confrontation with economic elites will lead to the adequate enforcement of institutions of production. Inclusive economic development is the reward for those countries that manage to do the latter.

\subsection{Mauritius}

Mauritius is a model case that demonstrates both inclusive structural transformation and primitive diversification. The so-called miracle case is so prominent that various perspectives on comparative development claim to explain the success that is Mauritius. One notable example is Robinson (2006), who explains the Guyana-Mauritius divergence on account of stronger protection of private property and democratic politics in Mauritius. We remain unconvinced with this narrative. While property rights protection and democracy are part of the Mauritian story, we argue that these are not fundamental causes of its relative development.

Central to the Mauritian story is its colonial history. France controlled the island until 1814, and crucially, the French plantocracy (henceforth franco-Mauritian plantocracy) remained in Mauritius under British control (Sandbrook 2005). Given the colonial past with Indo- and Afro-Mauritians, there was latent hostility against the franco-Mauritian plantocracy and even the British colonial state kept them at arms length. This was intensified after World War I when the plantocracy sought retrocession to France. For example, British judges often ruled in favour of Indo-Mauritians when employer and indentured labourer disputes emerged (Reddi 1997). More strikingly, Sandbrook argues that the British colonizers encouraged Indo-Hindu Mauritians to fill public bureaucracies as a means to counter the economic power of the plantocracy. 
Notwithstanding this tenuous relationship between the colonial state and franco-Mauritian plantocracy at the turn of independence in 1968, Meisenhelder (1999) noted that economic power still resided in the plantocracy but with a modification that included the creole elite. Bowman (1991: 119) estimates the top decile income share to be 46.7 percent in the 1970s. Further, Auty (2017) explains that the planters assembled a pro-growth political coalition to block a radical redistributive party and formed the first independent government. After a period of political crises in the immediate years following independence, an implicit bargain was struck between the plantocracy and the governing elites (Meisenhelder 1999; Seegobin and Collen 1977).

The central pillar of the bargain was a tax-supported welfare state rather than asset redistribution. While the tax on sugar exports may demonstrate the sincerity of the bargain, it was largely the outcome of good fortune. Subramaninan and Roy (2003) note that Mauritius was able to negotiate the largest sugar quota with the EEC/EU at a guaranteed price average of 90 percent greater than market price. Therefore, it is little surprise that a sugar tax was economically feasible and acceptable to the plantocracy. But over time, with the support of the IMF, the plantocracy pressured government to abolish the sugar tax in 1994 (Sandbrook 2005). This was surely related to the subsequent removal of preferential sugar prices.

We note the following points. First, the contestation between de jure and de facto political powers was mediated by the good fortune of sugar rents (Greenaway and Lamusse 1999; Subramaninan 2009). This provided government with a lucrative pool of tax revenue for purposes of diversification and the development of a welfare state. The latter was key to meeting important consumption needs so that the social peace can be maintained while wages were low (Meisenhelder 1999). Second, the sugar rents and abatement of underlying distributional conflict (through the development of the welfare state) made economic elites less likely to oppose any attempt at structural change.

The Mauritian state used the sugar revenue to ignite a process of industrialization. It established an Export Processing Zone (EPZ) in the 1970s, imposed foreign exchange controls, undertook import substitution industrialization strategies, infant industry protection and other forms of market control to enhance export competitiveness (Kothari 2013). Just to fix ideas consider the following. Carroll and Carroll (1997) show that industrial production as a percentage of GDP increased from 23 to 33 percent between 1965-1993 (on comparable terms to South Korea and Singapore for the same period) and by 1985 manufacturing had 
replaced sugar as the country's largest earner of foreign exchange (Kearney 1990). The EPZ was particularly attractive, especially to the franco-Mauritian plantocracy (Auty 2017). Its incentive scheme exempted employers from over time pay, maternity allowance, holiday work and termination of employment regulations. This is in striking contrast to the rest of the economy. For example, employers outside the EPZ needed to justify layoffs to a Termination Contracts and Services Board and compensate laid-off workers (Sandbrook 2005). This was Mauritius' attempt to address the distributional issues associated with structural change. Carroll and Carroll (1999) note that the governing elites widely consulted on policies and provided free health, education and pension services.

This process of structural change was growth enhancing and inequality reducing. Based on the World Income and Wealth Database (WID), Mauritius' top 1 percent fiscal income share reached a low of 3.9 percent in 2002 as compared to 11.2 percent in 1947. A similar pattern is observed for its top decile, which reached its trough in 2005 at 14 percent as compared to 21.6 percent in 1980. This has been a period of inclusive structural change - the Mauritius miracle. However, the early to mid 2000s marked the trough of the Kuznets wave and based on WID's data, top income shares are on an upward trend. This is corroborated by Bunwaree (2014), who uses Gini coefficients to demonstrate that inequality is on the rise since the early 2000s. We have explained the Kuznets wave as the outcome of structural changes, ergo, the recent rise of income inequality suggests that Mauritius is undergoing some form of primitive diversification. To this we now turn.

From the late 1980s to the early 1990s, the industrialization model was running out of steam as wages increased and cheaper competitors emerged (Auty 2017). Policy changed in the direction of promoting luxury tourism and financial services - primitive diversification. In the early 1990s, a stock market and an offshore banking centre were established with zero income tax incurred from offshore banking activities (Bunwaree 2014; Meisenhelder 1999). We argue that these fundamental changes in economic activities are the driving forces behind the recent upsurge in income inequality - a striking similarity to the Barbados case.

We take the following stock of the Mauritian miracle. First, the institutions of production promoted a growth-enhancing structural transformation. This industrialization period is hardly the consequence of simply protecting private property rights. Second, it was the good fortune of sugar rents that prevented economic elites from pushing Mauritius into the direction of primitive diversification; and loose labour laws and low wages that attracted economic elites to the EPZ. Third, it was the good sense of the Mauritian governing elite 
to pre-empt distributional conflict through the creation of a welfare state. In the absence of these, there would be no Mauritius miracle.

We argue that the fundamental cause of the Mauritian success was its good fortune of sugar rents that led to a compromise (between de facto and de jure political powers) of inclusive transformation. Our perspective on Mauritius warrants a short discussion on ethnic conflict, developmental state and politics in Mauritius. That Mauritius had a highly competent public service is a given - a necessary but not sufficient condition for inclusive transformation (as demonstrated by the recent rise of inequality). Moreover, its welfare state was for all Mauritians, irrespective of ethnicity, an important abatement of ethnic conflict. But the welfare state was not possible without the good luck of sugar rents. Further, Mauritius is a parliamentary democracy with coalitions that extend across class and ethnic lines. This increases group representation and reduces ethnic tensions. But while this form of parliamentary democracy promotes political stability, its growth and distributional payoffs are ambiguous in the absence of sugar rents and the sugar compromise.

\section{Conclusion}

This paper develops a conceptual framework and presents three case studies using a comparative historical analysis methodology that is substantivist in nature. The case studies show how differences in economic structures are the fundamental cause of differences in economic development. This insight is derived from a synthesis of competing hypotheses. A given economic structure gives rise to a particular distribution of income - an important source of de facto political power. The mechanics of economic change or dynamic under-development are in turn determined by the intensity of competition between de facto and de jure political powers and the resolution to this contestation. The protection of private property can be the underbelly of this contestation when property holders have close ties to a country's colonial past and/or when property holders are overwhelmingly of one ethnic group. Inclusive economic development occurs when a distributional bargain is struck and when economic change engenders a wider diffusion of skills and a lower hierarchy of occupational structurelower income inequality. The Mauritius case reveals that it was the good fortune of sugar rents that gave rise to a distributional bargain and institutions of production that led to the Mauritian miracle. Our theoretical framework and the history of Guyana, Barbados and Mauritius, reveal that the distribution of income and economic structure are two laws 
of motion that determine societal evolution. But our framing of the underlying cause of relative development is still incomplete, if only because these insights need to be formalized and verified by more historical cases and time-series econometric analyses.

\section{References}

Acemoglu, D., Johnson, S., and Robinson, J. (2003). Disease and Development in Historical Perspective. Journal of European Economic Association, 1(2-3):397-405.

Acemoglu, D., Johnson, S., and Robinson, J. (2005). Institutions as the Fundamental Cause of Long Run Growth. In Aghion, P. and Durlauf, S., editors, Handbook of Economic Growth. Harvard University Press.

Adamson, A. (1972). Sugar without Slaves: The Political Economy of British Guiana, 18381904. Yale University Press: New Haven and London.

Aghion, P., Alesina, A., and Trebbi, F. (2008). Democracy, Technology and Growth. In Helpman, E., editor, Institutions and Economic Performance. Cambridge, MA: Harvard University Press.

Alleyne, P., Charles-Soverall, W., Broome, T., and Pierce, A. (2017). Perceptions, Predictors and Consequences of Whistleblowwing among Accounting Employees in Barbados. Meditari Accountancy Research, 25(2):241-267.

Andreoni, A. (2014). Structural Learning: Embedding Discoveries and the Dynamics of Production. Structural Change and Economic Dynamics, 29(58-75).

Auty, R. M. (2017). Natural Resources and Small Island Economies: Mauritius and Trinidad and Tobago. Journal of Development Studies, 53(2):264.

Barrow, C. (1983). Ownership and Control of Resources in Barbados: 1834 to the Present. Social and Economic Studies, 32(3):83-120.

Beckles, H. (2007). A History of Barbados: From Amerindian Settlement to Nation-State. Cambridge University Press: Cambridge, New York. 
Bertola, L., Higashi, H., and Porcile, G. (2002). Balance-of-Payments-Constrained Growth in Brazil: A Test of Thrilwall's Law, 1890-1973. Journal of Post Keynesian Economics, 25(1):123-140.

Bourne, C. (1975). Review Article: The Plantation Economy of Guyana. Social and Economic Studies, 24(4):509-520.

Bowman, L. W. (1991). Mauritius: Democracy and Development in the Indian Ocean. Boulder, CO: London.

Bulmer-Thomas, V. (2012). The Economic History of the Caribbean since the Napoleonic Wars. Cambridge University Press: Cambridge and New York.

Bunwaree, S. (2014). The Fading Developmental State: Growing Inequality in Mauritius. Development, 57(3-4):578-590.

Carroll, B. W. and Carroll, T. (1997). State and Ethnicity in Botswana and Mauritius: A Democratic Route to Development? Journal of Development Studies, 33(4):464-486.

Carroll, B. W. and Carroll, T. (1999). Civic Networks, Legitimacy and the Policy Process. Governance, 12(1):1-28.

Chandisingh, R. (1983). The State, the Economy and Type of Rule in Guyana: An Assessment of Guyana's Socialist Revolution. Latin American Perspectives, 10(4):59-74.

Conceicao, P. and Galbraith, J. K. (2002). Technological Intensity and Inter-sectoral Dynamics of Inequality: Evidence from the OECD, 1970-1990. International Journal of Technology, Policy and Management, 2(3):315-337.

Constantine, C. (2016a). Changing the Rules vs. Breaking the Rules: Corruption in Rich and Poor Countries. Paper prepared for the Sixth LAEMOS Colloquium in Vina Del Mar, Chile on Subverting Corruption.

Constantine, C. (2016b). Economic Structure, Allocation of Human Capital and Growth. Paper prepared for the Golden Jubilee Symposium Series (23th-25th May): Guyana at 50, Understanding its Independence Journey, in Georgetown Guyana. 
Constantine, C. (2017a). A Community Divided: Top Incomes in CARICOM Member States. Paper prepared for the 18th Sir Arthur Lewis Institute of Social and Economic Studies, Annual Conference on Small Nations, Dislocations, Transformation: Sustainable Develoment in SIDS, in Trinidad and Tobago, April 26th-28th.

Constantine, C. (2017b). Economic Structures, Institutions and Economic Performance. Journal of Economic Structures, 6(2):1-18.

Constantine, C. (2017c). The Rise of Income Inequality in Guyana. Social and Economic Studies, 66(3\&4):65-95.

Cumper, G. (1962). The Differentiation of Economic Groups in the West Indies. Social and Economic Studies, 11(4):319-332.

DaCosta, M. (2007). Colonial Origins, Institutions and Economic Performance in the Caribbean: Guyana and Barbados. International Monetary Fund (IMF) Working Paper, $\mathrm{WP} / 07 / 43: 1$.

Danns, K. G. (1997). Race and Development in Plural Societies: The Case of Guyana. Caribbean Dialogue, 3(2):32-41.

Dasgupta, P. and Stiglitz, J. (1980). Industrial Structure and the Nature of Innovative Activity. Economic Journal, 90(358):266-293.

Dawson, A. (2011). State Authority Structures and the Rule of Law in Post-Colonial Societies: A Comparison of Jamaica and Barbados. PhD thesis, McGill University, Montreal.

Diamond, P. (1999). Guns, Germs and Steel: The Fate of Human Societies. W.W. Norton and Company, USA.

Downes, A. (1987). The Distribution of Household Income in Barbados. Social and Economic Studies, 36(4):127-155.

Dunn, R. S. (1969). The Barbados Census of 1680: Profile of the Richest Colony in English America. The William and Mary Quarterly, 26(1):3-30.

Engerman, S. L., Sokoloff, K., Urquiloa, M., and Acemoglu, D. (2002). Factor Endowments, Inequality and Paths of Development among New World Economies. Economia, Journal of the Latin American And Caribbean Economic Association, 3(1):41-109. 
Farley, R. (1954). The Rise of the Peasantry in British Guiana. Social and Economic Studies, 2(4):87-109.

Farley, R. (1964). The Rise of the Village Settlements in British Guiana. Caribbean Quarterly, 10(1):52-61.

Galbraith, J. K. and Berner, M., editors (2001). Inequality and Industrial Change: A Global View. Cambridge University Press.

Greenaway, D. and Lamusse, R. (1999). Private and Public Sector Responses to the 19721975 Sugar Boom in Mauritius. In Collier, P. and Gunning, J. W., editors, Trade Shocks in Developing Countries, Volume 1 Africa. Oxford University Press: Oxford.

Grenade, K. and Lewis-Bynoe, D. (2011). Reflecting on Development Outcomes: A Comparative Analysis of Barbados and Guyana. Journal of Eastern Caribbean Studies, 36(1):2142.

Hartmann, D. (2014). Economic Complexity and Human Development: How Economic Diversification and Social Networks Affect Human Agency and Welfare. Routledge.

Hartmann, D., Guevara, M., Jara-Figueroa, C., Aristaran, M., and Hidalgo, C. (2017). Linking Economic Complexity, Institutions and Income Inequality. World Development, 93:75-93.

Hartmann, D., Jara-Figueroa, C., Guevara, M., Simoes, A., and Hidalgo, C. (2016). The Structural Constraints of Income Inequality in Latin America. Integration and Trade, 40:70-85.

Hidalgo, C., Hausmann, R., and Dasgupta, P. (2009). The Building Blocks of Economic Complexity. Proceedings of the National Academy of Science of the United States of America, 106(26):10570-10575.

Hussain, M. N. (1999). The Balance of Payments Constraint and Growth Rate Differences Among African and East Asian Economies. African Development Review, 11(1):103-137.

Ishmael, A. W. (1993). Urbanization in a Peripheral Capialist State: A Guyana Case Study. PhD thesis, Portland State University. 
Josiah, B. (1997). After Emancipation: Aspects of Village Life in Guyana, 1869-1911. Journal of Negro History, 82(1):105-121.

Kaplan, S. N. and Rauh, J. (2010). Wall Street and Main Street: What Contributes to the Rise in the Highest Incomes? Review of Financial Studies, 23(3):1004-1050.

Kearney, R. C. (1990). Mauritius and the NIC Model Redux: Or, How Many Cases Make a Model? Journal of Developing Areas, 24(2):195-216.

Khemraj, T. (2015). The Colonial Origins of Guyana's Underdevelopment. Social and Economic Studies, 64(3-4):151-185.

Khemraj, T. (2016). The Political Economy of Guyana's Underdevelopment. Review of Black Political Economy, 43(3-4):325-342.

Kothari, U. (2013). Geographies and Histories of Unfreedom: Indentured Labourers and Contract Workers in Mauritius. Journal of Development Studies, 49(8):1042-1057.

Machiavelli, N. (2009 [1531]). Discourses on Livy. Oxford University Press: Oxford and New York.

McCombie, J. S. L. (1997). On the Empirics of the Balance of Payments Constrained Growth. Journal of Post Keynesian Economics, 19(13):345-375.

Meisenhelder, T. (1999). The Developmental State in Mauritius. Journal of Modern African Studies, 35(2):279-297.

Moore, L. B. (1975). The Social Impact of Portuguese Immigration into British Guiana after Emancipation. Boletin de Estudios Latinoamericanos y del Caribe, 19:3-15.

Nicholls, W. (1969). Barbados: A Case Study of the Plantation Economy. Master's thesis, McGill University.

North, D. (1990). Institutions, Institutional Change and Economic Performance. Cambridge University Press: New York.

North, D. (1991). Institutions. Journal of Economic Perspectives, 5(1):97-112.

Onafowora, O. A. and Owoye, O. (2012). Modelling International Tourism Dmand for the Caribbean. Tourism Economics, 18(1):159-180. 
Piketty, T. (2014). Capital in the Twenty-First Century. Harvard University Press.

Potter, R. B. (1981). Industrial Development and Urban Planning in Barbados. Geography, 66(3):225-228.

Prebisch, R. (1950). The Economic Development of Latin America and its Principal Problems. Economic Bulletin for Latin America, 7:1-12.

Premdas, R. (2013). Social Policies in Barbados. UNRSID and Commonwealth Secretariat.

Rappaport, J. and Sachs, J. D. (2003). The United States as a Coastal Nation. Journal of Economic Growth, 8(1):5-46.

Reddi, S. J. (1997). The Making of a British Colonial State in 19th Century Mauritius. Conference on the British Legacy, Mahatma Gandhi Institute, Reduit, 6-9 May.

Reinert, E. (2007). Institutionalism Ancient, Old and New: A Historical Perspsective on Institutions and Uneven Development. In Chang, H. J., editor, Institutional Change and Economic Development, chapter 4, pages 53-72. Anthem Press.

Reinert, E. (2016). Giovanni Botero (1588) and Antonio Serra (1613): Italy and The Birth of Development Economics. In Erik S. Reinert, J. G. and Kattel, R., editors, Handbook of Alternative Theories of Economic Development, pages 3-37. Edward Elgar Publishing Ltd.

Robinson, J. (2006). Equity, Institutions and the Development Process. Nordic Journal of Political Economy, 32:17-50.

Rodney, W. (1981). Plantation Society in Guyana. Review Fernand Braudel Center, 4(4):643-666.

Sachs, J. D. (2001). Tropical Underdevelopment. National Bureau of Economic Research, Working Paper no. 8119.

Sachs, J. D. and Malaney, P. (2002). The Economic and Social Burden of Malaria. Nature, 415(6872):680-685.

Sachs, J. D. and Warner, M. (2001). The Curse of Natural Resources. European Economic Review, 45(4-6):827-838. 
Sandbrook, R. (2005). Origins of the Democratic Developmental State: Interrogating Mauritius. Canadian Journal of African Studies, 39(5):549-581.

Seegobin, R. and Collen, L. (1977). Mauritius: Class Forces and Political Power. Review of African Political Economy, 8:109-118.

Singer, H. (1950). The Distribution of Gains Between Investing and Borrowing Countries. American Economic Review, Papers and Proceedings, 40(2):473-485.

Stiglitz, J. (2013). The Price of Inequality. W.W. Norton and Company.

Subramaninan, A. (2009). The Mauritian Success Story and Its Lessons. UNU/WIDER Research Paper No. 2009/36.

Subramaninan, A. and Roy, D. (2003). Who Can Explain the Mauritian Miracle? Meade, Romer, Sachs, or Rodrik? In Rodrik, D., editor, In Search of Prosperity, pages 205-243. Princeton University Press: Princeton.

Taeuber, I. (1952). British Guiana: Some Demogracphic Aspects of Economic Development. Population Index, 18(1):3-19.

Tennyson, J. and Barrow-Giles, C. (2008). Model Democracy or Groundless Complacency? An Exploration of Democracy and Governance in Barbados Around the Issues of the 2008 General Election. Paper prepared for the Caribbean Studies Association Conference San Andreas, Colombia, May 26-June 1st, 2008.

Thirlwall, A. (1979). The Balance of Payments Constraint as an Explanation of International Growth Rate Differences. Banca Nazionale del Lavoro Quarterly Review, 32(128):45-53.

Thomas, C. Y. (1988). The Poor and the Powerless: Economic Policy and Change in the Caribbean. London: Latin America Bureau.

Wager, J. M. (1975). Structural Pluralism and the Portuguese in Nineteenth Century British Guiana: A Study in the Historical Geography. PhD thesis, McGill University.

Williams, E. (1945). The Historical Background of British Guiana's Problems. Journal of Negro History, 30(4):357-381. 